\title{
The Implementation of the Polya Method in Solving Euclidean Geometry Problems
}

\author{
Akhsanul In'am ${ }^{1}$ \\ ${ }^{1}$ Mathematics Department, University of Muhammadiyah, Malang, Indonesia \\ Correspondence: Akhsanul In'am, Mathematics Department Faculty of Teacher Training and Education \\ University of Muhammadiyah Malang, Jl. Raya Tlogomas No. 246, Malang, Indonesia. E-mail: \\ ahsanul_in@yahoo.com
}

Received: April 1, 2014 Accepted: May 2, 2014 Online Published: June 27, 2014

doi:10.5539/ies.v7n7p149 URL: http://dx.doi.org/10.5539/ies.v7n7p149

\begin{abstract}
This research is aimed at analyzing the solutions of Euclidean Geometry problems using the Polya method. This present study was made through qualitative and quantitative approaches with 85 respondents of the second semester students at the Department of Mathematics Education, University of Muhammadiyah Malang Indonesia, in the 2012/2013 academic year. The quantitative study was made through instruments used to understand students' responses to the implementation of the Polya method and to know their capabilities in solving two Euclidean Geometry problems. All instruments before being applied were tested for their validity and reliability, and the tests show that the instruments have fulfilled validity and reliability requirements. Qualitative study was made to reinforce the results through interviews to 6 students chosen from those in the low, medium and good levels. The results show that in terms of their understanding of the problems, majority students are good. Dealing with the planning of problems solution, the results show that the majority students made such plans. Then for the carry out the plan, all students did implementation, but for look back, most students did not make any review.
\end{abstract}

Keywords: understand the problem, devise a plan, carry out the plan, look back

\section{Introduction}

Problem solving is a mental process requiring one to think critically and creatively, to look for alternative ideas and specific steps in order to cope with any hindrances or flaws (Mardzelah, 2007). It is also stated that problem solving is an approach to solve a certain problem (Wahyudin, 2010), besides problem solving is a characteristic of mathematics and medium for the development of mathematical knowledge (Rahman, 2003). Problem solving is the foundation of various mathematics activities (Reys, 2004), as well as cognitive activities involving processes and strategies (Gagne \& Briggs, 1979).

The implementation of problem solving needs one to think critically and creatively and it is a systematic process (Yahaya, 2005). It is a very important activity either for the present or future condition so that a pattern is necessary in order to be able to solve problems. A creative product must be preceded by the construction of a creative idea produced through a thinking process involving cognitive activities called a creative thinking process. This creative thinking is as a process of creativity and refers to any individual efforts to produce creative products (McGregor, 2007). The ability of mathematical creative thinking is the capability to find out a solution to a mathematic problem easily and flexibly (Park, 2004), while creativity may be viewed from the process of solving the problem (Dickhut, 2007).

From the description above, it is shown that in the process of problem solving, critical thinking is necessary, so that after students understand the problems, they make plans to solve them and in such planning, bright ideas are needed in order to be able to find the solutions effectively and accurately. The bright ideas may be obtained if critical thinking is always employed in viewing every problem, where creative thinking is gained through thinking.

Thinking is an extraordinary process employed to find understanding (Lim, 2009), meanwhile creative thinking is a conscious effort involving creative ideas and actions on a concept and approach (Mardzellah, 2007). Successful thinking through creative thinking is a principle in solving any problems.

Euclidean geometry is one of obligatory subjects to obtain undergraduate at the Mathematics Department, University of Muhammadiyah Malang, Indonesia. The objective of this subject is to provide students with 
knowledge and direction to make them able to comprehend a problem and to make a plan to solve it through logical and systematic stages on the basis of reliable bases, theorems, and definitions. Based on the facts the research found in the class, it is found out that students often did not make any plan in solving problems. This is also the case in the reviewing activities. It is due to the fact that the students feel that their obtained answers have been correct, and some other students could not manage the time well, so that the allotted time to solve the problems is over. Therefore, in this present study, the problems to answer are as follows: 1) how do students understand the Euclidean geometry problems? 2) how do students plan to devise a plan the Euclidean geometry problems?; 3) how do students carry out the plan the Euclidean geometry problems? and 4) how do students look back the solutions to the Euclidean geometry problems?

\section{Review of Literature}

Some experts say that the definitions of solutions to mathematic problems are difficult to understand (Mamona-Downs \& Downs, 2005). Some others said that some definitions might be said to be less acceptable according to the thought development (Lesh, Hamilton, \& Kaput, 2006; Lesh, Zawojewski, and Carmona, Roger, 2004) proposed that less exercises which teachers assign to the students as the cause of the students' difficulty in solving problems, most students had a low motivation to look for alternative answers to a problem. This shows that intrinsic motivation is really needed to try to solve any problems, and innovation and creativity are components required to solve mathematic problems (Schoenfeld, 1985).

Each creature living in this un-endless earth must have problems, either internal or external factors. As a creature, one should always have positive thinking, meaning that any problems arising in this life must have solutions. This is also the case in learning. Problems must arise in terms of material delivery, namely teachers, or the material itself, students. Concerning with material, mathematic material, various methods and stages to solve them have been proposed by experts in this field. In mathematics, problem solving is all activities included in problems dealing with mathematic language, techniques of problem solving and the use of mathematic competence to solve problems.

\subsection{Characteristics of Solving Mathematic Problems}

Each step in solving problems possesses different characteristics from one problem to another. This also happens in mathematics, where a problem solving adopted also shows a specific characteristics and this should be known before solving a problem. Some knowledge and comprehension of characteristics of a problem might help find an appropriate and intended solution.

There are some characteristics of problem solving in mathematics: 1) appropriate strategies are necessary in problem solving; 2) possessed knowledge is important in resulting wrong solution; 3) levels of skills in problem solving really affect accuracy and suitability of the obtained results in doing problem solving; 4) problem solving is not based on the possessed memory; 5) each problem possesses unique strategies; 6) various approaches should be learned and understood to result in appropriate and expected problem solving; 7) knowledge and skills in applying mathematic concepts and principles that have been learnt really helpful to solve problems (In'am, 2012).

Schoenfeld (1992), explained that distinctive situation could use different problem solving strategies, whereas Lester (1994), explained that there are six methods for problem solving, as follows: 1) realizing problems; 2) understanding problems; 3) analyzing the aim; 4) planning the strategy; 5) implementing the strategy and 6) evaluating the obtained results.

\subsection{Types of Problems and Steps in Solving Them}

Each problem must have familiar characteristics and types, as an effort to facilitate the design and determination of strategies, approaches, and methods appropriate to solve it. Principally, types of problem solving in mathematics consist of two namely routine and non-routine problems.

\subsubsection{Routine Problems}

Each activity might be grouped into any problems which are usually found out in daily life and this is called routine problems. The next is those of which their comings are not expected and might not be figured, and they are called non-routine problems. In mathematics, routine problems are the type of mathematic ones where the forms are technical. Any effort to solve routine problems is intended to gain a good basic ability, especially arithmetic ability involving four basic operations in mathematics, namely addition, subtraction, multiplication, and division. Direct application also makes the use of mathematic formulas, laws, theorems and equation. 


\subsubsection{Non-Routine Problems}

Non-routine problems are various unique ones that need the application of skills, concepts or principles that have been learned to solve them. Solutions to non-routine mathematic problems do not require memories and the answers are relatively various. The process of problem solving needs systematic activities with logical planning, including appropriate strategies and methods in the implementation.

After knowing types of problems to solve, the next step is to look for solutions on the basis of steps to do. Problem identification is a process to understand and to know certainly aspects existing in the problem. Each problem possesses different aspects, and it is necessary to know this as a step to determine an appropriate approach, method and strategy to solve the problem. After examining and the problem identification, various important and necessary information is obtained in order to determine further steps in solving the problem. This stage is intended to obtain information, including materials, and facts dealing with the problem.

The next step is to give a tentative answer on the basis of the obtained information, combined with the possessed knowledge and experiences. This stage serves as consideration to determine the strategy and method applied in solving the problem, and then the next is to test the hypothesis that has been made from the consideration of strategies and method implemented in the process of problem solving. The last stage is to make an evaluation and to draw conclusion dealing with the result obtained as a proper conclusion for solving the problem.

\subsection{The Polya Method to Solve Problem}

Problems in solving mathematic problems results in various ideas from different experts to solve problems which are expressed in models of problem solution, and one of the experts is George Polya. In 1957, he succeeded in applying the mathematic model for solving problems. This model is called the Polya method. According to Polya, in solving mathematic problems, four stages may be made: understanding the problem, planning strategies for problem solving, carrying out the problem and looking back the obtained result.

The Polya method has much been implemented to solve mathematic problems at elementary, secondary and tertiary levels. This method guides students to make stages and steps in solving problems, and also to complete the result by looking back it. This condition actually is almost the same with general principles in managing or doing an activity, namely making plan, organizing the concerned aspects, making and controlling activities and obtained result. This study was once made by Manoy (2009) examining students' thinking plots in solving mathematic problems through Polya steps. The following is presented the four stages Polya proposes.

\subsubsection{Understand the Problems}

Understanding is an activity that should be done before making activities of problem solving. As John Dewey suggests, the first stage to solve a problem is to look for information on the problem. It means that by looking for information on various aspects, a step to understand the problem to be solved is made. There are various ways to understand the problem namely: 1) identification of variables concerning with the problem; 2) relationship between variables that have been determined and 3) variables needed through studies or answers.

\subsubsection{Devise a Plan}

After identifying problem, the next step is to make a direction to plan appropriate strategies to solve the problem. Understanding of the problem results in various aspects needed to determine the plan to solve the problem. In making any activity, planning involving strategies, approaches and methods appropriate to solve a problem should be made to guarantee that the implementation will be successful. There are some aspects to be prepared in making a plan to solve a problem, namely: 1) choose stages in accordance with the obtained information on the problem to solve; 2) make an appropriate diagram, and this might help to determine appropriate step in solving the problem; 3) make an analogy, as an effort to determine an appropriate strategy, approach and method by making analogy with the relatively similar problems, since different problems need different approaches and not each strategy, approach and method might be used to solve all problems.

\subsubsection{Carry Out the Problem}

Understanding a problem, and then making a good plan to solve the problem will not be useful if it has not been implemented. An effort to show that the problem solving is suitable for solving the problem is by implementing the problem solving in line with the chosen approach, strategy and model.

\subsubsection{Look Back}

Anything which human being made sometimes is planned, sometimes not; it is also the case in implementing a plan. An effort should be made in solving a problem to review the obtained answers. The activity might be done by using the answer through inverse method, so that it can be seen whether the answer is really appropriate with 
the one expected from the problem, for example. For the problem dealing with multiplication, it might be done by looking back through steps of division.

\section{Methodology}

\subsection{Research Design and Setting}

This study is aimed at analyzing the implementation of the Polya method in solving Euclidean geometry problems. Researchers recognize that each approach employed in a research possesses strengths and weaknesses, and to complete the results of this research. Quantitative and qualitative approaches were adopted. Quantitative analysis was used to analyses instruments dealing with the students' responses to the use of the Polya method, and complemented with qualitative analysis.

\subsection{Participants}

Respondents in this research are the 85 second semester students of the Mathematics Department, Faculty of Teacher Training and Education, University of Muhammadiyah Malang, Indonesia, consisting of two classes.

\subsection{Instrument}

There were two instruments employed in this present research, as follows: 1) the one to know students' responses to the implementation of learning using the Polya method consisting 16 items; 2) the materials tests of Euclidean Geometry of two problems in order to know the solving problems that students made concerning with the model developed in this research.

As usual, the instruments employed should fulfill validity and reliability requirements. Therefore, Validity and reliability tests to the instruments were made to 46 students of non-respondents in this research. The results of the validity test showed that the two problems had the coefficient of 0.81 and 0.82 respectively, showing that the two showed a level of validity, and the reliability test resulted in the coefficient of 0.67 , which is at a level of category.

Meanwhile, the results of the validity test to each 16 test items concerning with students' responses to the implementation of the Polya method are as follows $0.50 ; 0.56 ; 0.61 ; 0.47 ; 0.23 ; 0.46 ; 0.52 ; 0.60 ; 0.54 ; 0.57$; $0.596 ; 0.53 ; 0.50 ; 0.46 ; 0.60$ and 0.59 and the coefficient of the instrument reliability for the implementation of the Polya method is 0.73 . Based on the results, it is shown that all the instrument items fulfill requirements of validity as well as reliability.

\subsection{Data Collection, Procedure and Analysis Data}

This research was made in two stages. First data were obtained from instrument the students filled in order to understand their responses to the implementation of the Polya method in solving Euclidean Geometry problems. Then the frequency, average and percentage were made. Then, using a qualitative study, six students were chosen to understand the results of students' capability in solving Euclidean Geometry problems. The results of the tests were classified into three categories: low, average and good. Two respondents were taken from each category. The study was made through interviews to analyses the use of the Polya method in solving Euclidean geometry problems.

\section{Findings}

Based on the instruments used to understand the students' responses to the aspects in solving problems in accordance with Pole consisting of four stages; understanding, planning, implementing and look back the obtain results, the results (as shown in the following tables) were obtained. Then, as a step to strengthen the obtained results based on the instruments, results based on the interviews were made to six students by taking two students of each category from low, average and good levels of capability described. 
Table 1. Students' responses to the aspect of understanding

\begin{tabular}{cccccc}
\hline \multirow{2}{*}{ Item } & \multicolumn{5}{c}{ Responses } \\
\cline { 2 - 5 } & Low & Average & Good & $\begin{array}{c}\text { Very } \\
\text { Good }\end{array}$ & Average \\
\hline I try to understand the goal of a problem before answering & 1 & 19 & 38 & 27 & 3.07 \\
the problem & $1.2 \%$ & $22.4 \%$ & $44.7 \%$ & $31.8 \%$ & \\
I think of the meaning of a problem before I start to answer & 3 & 21 & 45 & 16 & 2.49 \\
the problem & $3.5 \%$ & $24.7 \%$ & $52.9 \%$ & $18.8 \%$ & \\
& 9 & 20 & 36 & 20 & 2.60 \\
I know how many problems that I can accomplish & $10.6 \%$ & $23.5 \%$ & $42.4 \%$ & $23.5 \%$ & \\
& 0 & 16 & 48 & 21 & 3.16 \\
I try to understand a problem before I try to solve them & $0 \%$ & $18.8 \%$ & $56.5 \%$ & $24.7 \%$ & \\
\hline Average & 3.25 & 19 & 41.75 & 21 & 2.83 \\
\hline
\end{tabular}

Based on Table 1, it is shown that students' responses to the implementation of the Polya method showed the highest average in understanding problems before accomplishing them with the average of 3.16, while the lowest results dealing with the meaning of problems to solve with the average of 2.49 , the information showed that although students understand the problems to solve, they have less understanding to the problems.

If the responses are classified into two, good and less, the table informs that the majority students showed good responses, it is shown from the frequency and percentage of $62.75(73.8 \%)$. The condition is supported by the results of interviews with respondents with the code of R1/A as follows:

...ee. Dealing with the solution of problems, I can understand the problem before solving it...but sometimes I do not fully understand the meaning of the problem.. though I can understand it...

This condition is clarified by a respondent with average capability with the code of R3/B who showing his opinion as follows:

...the preliminary step I take before doing the problem ...ee...reading the problem to be able to understand the problem that I will do... reading once ... sometimes I can understand it..., but once I should also read it twice...even sometimes three times...I can understand the problem...

Based on the statement above, it can be said that the first aspect in the Polya method deals with understanding problems, and the majority students can understand the problem to solve, although they sometimes cannot understand the problem fully. The process of understanding a problem is made by reading it first, although sometimes they should read it twice in order to understand it. 
Table 2. Students' responses to the aspect of planning

\begin{tabular}{|c|c|c|c|c|c|}
\hline \multirow[b]{2}{*}{ Item } & \multicolumn{4}{|c|}{ Responses } & \multirow[b]{2}{*}{ Average } \\
\hline & Low & Average & Good & $\begin{array}{l}\text { Very } \\
\text { Good }\end{array}$ & \\
\hline \multirow{2}{*}{ I always make plan before solving problems } & 12 & 32 & 28 & 13 & \multirow{2}{*}{2.87} \\
\hline & $14.1 \%$ & $37.6 \%$ & $32.9 \%$ & $15.3 \%$ & \\
\hline \multirow{2}{*}{ I try to determine what to be required in solving problems } & 2 & 21 & 50 & 12 & \multirow{2}{*}{2.85} \\
\hline & $2.4 \%$ & $24.7 \%$ & $58.8 \%$ & $14.1 \%$ & \\
\hline \multirow{2}{*}{ I realize about the importance of planning my action } & 4 & 17 & 35 & 29 & \multirow{2}{*}{2.98} \\
\hline & $4.7 \%$ & $20.0 \%$ & $41.2 \%$ & $34.1 \%$ & \\
\hline \multirow{2}{*}{$\begin{array}{l}\text { I choose and organize proper information to solve } \\
\text { problems }\end{array}$} & 2 & 21 & 45 & 17 & \multirow{2}{*}{2.71} \\
\hline & $2.4 \%$ & $24.7 \%$ & $52.9 \%$ & $20.0 \%$ & \\
\hline \multirow{2}{*}{ Average } & 5 & 22.8 & 39.5 & 17.8 & \multirow{2}{*}{2.86} \\
\hline & $5.9 \%$ & $26.8 \%$ & $46.5 \%$ & $20.6 \%$ & \\
\hline
\end{tabular}

Table 2 shows students' responses to the implementation of solving problems based on their understanding. If they are grouped into two, namely good and less categories, it is known that good responses show the frequency and percentage of $57.3(67.1 \%)$. It shows that the majority students have good responses to the planning in solving problems. Concerning with the highest average in responding planning, students realize, 98 which is in line with their capability in organizing information as a medium to make a plan.

From the average as a whole, it is shown that planning which students make shows average of 2.86 , which is included into good category, meaning that generally student can make planning after understanding problems to solve. This information is asserted from the results of interviews with respondent with the code of R4/B as follows:

After I can understand the problem...usually I make a plan in terms of the steps I should take before continuing to the next process...but sometimes I also do not a detailed plan...since I have known what steps to do in solving the problem...

The results of the interviews inform that respondents usually make a plan before continuing solving a problem, but sometimes they do not make any plan, since the problem has been understood and they directly solve the problem. Therefore, when student may understand the problem and they feel that they do not have any problem, the planning is not made in a written form, but it happens in their mind and they directly solve the problem.

Table 3 describes the students' responses in terms of the implementation in solving geometry problems. The obtained information suggests that as a whole the average is 2.83 , showing that the students' responses to the aspect of implementation might be said to be in a good category. Viewed from each item, it can be understood that understanding to do and what steps to implement it shows the average responses of 2.30 , and the lowest score is on the item on how to accomplish the problem with the average of 2.47. If the responses are classified into two categories, good and less, it can be known that good responses possess the frequency of 57.3, while from the percentage, the average score is $67.7 \%$. The less category shows the frequency and percentage of 27.5 $(32.4 \%)$. The results are in line with what is informed by respondent R6/S based on the following interview:

...usually after reading a problem...if I understand what to do...I directly do the problem...by making a schema to facilitate the finishing of the problem but sometimes...I also have less understanding of the problem...but I always try to finish it... 
Table 3. Students' responses to the aspect of implementing

\begin{tabular}{|c|c|c|c|c|c|}
\hline \multirow[b]{2}{*}{ Item } & \multicolumn{4}{|c|}{ Responses } & \multirow[b]{2}{*}{ Average } \\
\hline & Low & Average & Good & $\begin{array}{l}\text { Very } \\
\text { Good }\end{array}$ & \\
\hline \multirow{2}{*}{ I try to solve a problem based on the plan I have made } & 8 & 33 & 29 & 15 & \multirow{2}{*}{2.79} \\
\hline & $9.4 \%$ & $38.8 \%$ & $34.1 \%$ & $17.6 \%$ & \\
\hline \multirow{2}{*}{ I try to find the main idea before solving the problem } & 1 & 23 & 38 & 23 & \multirow{2}{*}{3.05} \\
\hline & $1.2 \%$ & $27.1 \%$ & $44.7 \%$ & $27.1 \%$ & \\
\hline \multirow{2}{*}{$\begin{array}{l}\text { I make certain to understand what to do and how to } \\
\text { implement it }\end{array}$} & 2 & 16 & 47 & 20 & \multirow{2}{*}{3.00} \\
\hline & $2.4 \%$ & $18.8 \%$ & $55.3 \%$ & $23.5 \%$ & \\
\hline \multirow{2}{*}{ I determine the ways to solve the problem } & 0 & 27 & 44 & 14 & \multirow{2}{*}{2.47} \\
\hline & $0 \%$ & $31.8 \%$ & $51.8 \%$ & $16.5 \%$ & \\
\hline \multirow{2}{*}{ Average } & 2.75 & 24.75 & 39.5 & 18 & \multirow{2}{*}{2.83} \\
\hline & $3.2 \%$ & $29.2 \%$ & $46.5 \%$ & $21.2 \%$ & \\
\hline
\end{tabular}

Based on the results shown in Table 4 dealing with the students' responses to the aspect of look back in highest average score in this aspect is awareness that in solving a problem it is necessary to review (3.06). Meanwhile the lowest average score deals with how many problems that can be solved $(2.85 \%)$.

Table 4. Students' responses to the aspect of look back

\begin{tabular}{|c|c|c|c|c|c|}
\hline \multirow{2}{*}{ Item } & \multicolumn{4}{|c|}{ Responses } & \multirow{2}{*}{ Average } \\
\hline & Low & Average & Good & Good Very & \\
\hline \multirow{2}{*}{ I realize that each solution should be reviewed } & 6 & 14 & 25 & 40 & \multirow{2}{*}{3.06} \\
\hline & $7.1 \%$ & $16.5 \%$ & $29.4 \%$ & $47.1 \%$ & \\
\hline \multirow{2}{*}{ I examine the solution I have made } & 5 & 29 & 37 & 14 & \multirow{2}{*}{2.91} \\
\hline & $5.9 \%$ & $34.1 \%$ & $43.5 \%$ & $16.5 \%$ & \\
\hline \multirow{2}{*}{ I almost always know how many problems I can solve } & 8 & 38 & 30 & 9 & \multirow{2}{*}{2.85} \\
\hline & $9.4 \%$ & $44.7 \%$ & $35.3 \%$ & $10.6 \%$ & \\
\hline \multirow{2}{*}{ I examine the accuracy of the results after solving problems } & 3 & 23 & 37 & 22 & \multirow{2}{*}{2.92} \\
\hline & $3.5 \%$ & $27.1 \%$ & $43.5 \%$ & $25.9 \%$ & \\
\hline \multirow{2}{*}{ Average } & 5.5 & 26 & 32.25 & 21,25 & \multirow{2}{*}{2.94} \\
\hline & $6.5 \%$ & $30.6 \%$ & $37.9 \%$ & $25.0 \%$ & \\
\hline
\end{tabular}

What is shown from the description above can be reinforced by the result of an interview with the respondent with the code of R6/B as follows:

After I solve a problem, I rarely review the results, it is because I feel sure that the results are really in line with what is asked...Though sometimes I am not so sure...but the time allotment is very limited...so I cannot review it.

Viewed from the category of students' responses to the aspect of look back, majority students are in a good category with the average score and percentage of 32.25 (37.9\%), and it shows an average category.

\section{Discussion}

The descriptions above, especially those dealing with understand the problems before making any plans, are in line with the results of Rajagukguk's (2011) study, that in his study, it is necessary to improve students' capability in understanding problems using Bruner theory. But in Haryani's (2012) study, it is shown that the 
senior high school students becoming the respondents in other studies did not have any difficulty in understanding mathematic problems, in this case viewed from their cognitive power. Therefore, in understanding a problem, it needs some improvements in students' capabilities, either through learning or drills, so that they might understand well the problems to solve.

Difficulties happened when making plans, where it is in line with the Komariah's (2011) study, that in her research, it is found that students did not find any problem when understanding problems, but in making plans, they faced some hindrances, and this is caused by their limited insights on the concepts dealing with the ones they studied and their less capabilities in making early understanding of the study in line with the problems to solve. The result is also in line with Sukayasa's (2012) study that students are necessary to be trained to present ideas, so that they would be able to make some plans of solving problems better.

The results of the interview show that students generally must do the test, after they have understood what is meant by the problem, but in practice, they always try to finish the problem. This result is also in line with Sukayasa's (2012) study, that the devise a plan of solving problems in the Polya stages is effectively made by students

Look back is the stage necessarily emphasized in the process of problem solving and the important stage compared with the obtained results (Huang et al., 2012). These results clarified that the majority respondents did not make some review of their solutions they had made (In'am, 2010), while Anggo (2011) based on the results of his research showed that for contextual problems, students show good results in solving problems, but for non-routine problems, they had some weaknesses in solving them. While in general, Lojinin (2008), from his research, showed that problem solving using the Polya approach could be made well, and in this case it was undertaken through Problem Based Learning.

Four Polya stages can improve the ability in solving mathematic problems as well as the level of students' rationality (Yuan, 2013). Concerning this explanation, it is necessary to have learning planning which can improve the ability of problem solving. The strategies of problem solving can improve metacognition and the ability of mathematics communication thinking (Bender, 2005; Van de Walle, 2004), whereas the improvement of problem solving ability can be implemented through learning by making the planning in solving problem (Bender, 2005; Schoenfeld, 1992)

\section{Conclusion}

On the basis of the description of the results of research, some conclusions can be made in terms of the implementation of the Polya method in solving Euclidean Geometry problems as follows: 1) understanding of Euclidean Geometry problems in general can be made by students before they implement the aspect of further problems; 2) planning as a second step in solving problems is made by students, but some of them do not do this step; 3 ) the aspect of the implementation of solving problems as a whole had been done by the student, but since some of them could not understand the problems well, although this aspect was done, they could not certainly solve the problems correctly and 4) in the aspect of look back, although students understand that this aspect is important to do, but in practice the majority of the students do not do it. It is because they are sure that what they do is right and some think the time is over.

From the descriptions above, it is suggested that the implementation of solving Euclidean geometry problems is in line with the expected goal, and teachers should give an emphasis on the students, so that the process of solving problems really make the use of steps consisting of four aspects namely understand the problem, devise a plan, carry out the plan and look back. For the last aspect, the majority students do not do it although they state that this aspect is important, therefore in teaching of Euclidean Geometry should provide students with some knowledge to do this as a mean to know whether their obtained answers have been right or not. Moreover, teachers should give insights of how to manage time when solving problems, so that there is a chance to review their obtained answers.

\section{References}

Anggo, M. (2011). Pelibatan metakognisi dalam pemecahan masalah matematika. Edumatica Volume 01 Nomor 01, April 2011 ISSN: 2088-2157.

Bender, W. (2005). Differentiating math instruction: Strategies that work for K-8 classrooms. Thousands Oaks, CA: Corwin Press.

Dickhut, J. E. (2007). A Brief Review of Creativity. Retrieved March 8, 2009, from http://deseretnews.com/dn/view/0,1249,510054502,00.html 
Gagne, R. M., \&, Briggs, L. J. (1979). Principles of Instructional Design (2nd ed.). New York: Holt, Rinehart and Winston. Trans. Mochidome, Hideyo (in press) Kyojusekkeino-genri.

Haryani, D. (2012). Profil proses berpikir kritis siswa sma dengan gaya kognitif Field independen dan berjenis kelamin laki-laki dalam memecahkan masalah matematika. Prosiding SNPM Universitas Sebelas Maret 2012.

Huang, T.-H., Liu, Y.-C., \& Chang, H.-C. (2012). Learning Achievement in Solving Word-Based Mathematical Questions through a Computer-Assisted Learning System. Educational Technology \& Society, 15(1), 248-259.

In'am, A. (2012). Model Pembelajaran Matematika berbasis Metakognitif. Malang: Selaras.

Komariah, K. (2011). Penerapan Metode Pembelajaran Problem Solving Model Polya untuk Meningkatkan Kemampuan Memecahkan Masalah bagi Siswa Kelas IX J di SMPN 3 Cimahi. Prosiding Seminar Nasional Penelitian, Pendidikan dan Penerapan MIPA, Fakultas MIPA, Universitas Negeri Yogyakarta, 14 Mei 2011

Lesh, R., Hamilton, E., \& Kaput, J. (Eds.). (2006). Models and modeling as foundations for the future of mathematics education. Mahwah, NJ: Lawrence Erlbaum Associates.

Lester Jr., F. K. (1994). Musings about mathematical problem-solving research: 1970-1994. Journal for Research in Mathematics Education, 25(6), 660-675. http://dx.doi.org/10.2307/749578

Lim, K. H. (2009). Seni Pemikiran Kritis, Suatu Pendekatan Logik Tak Formal. Kualalumpur: Dewan Bahasa dan Pustaka.

Lojinin, N. I. (2008). Kesan Strategi Pengajaran Problem Based Learning terhadap Pencapaian Matematik, Keberkesanan Pengajaran dan Atribut Afektif di Sekolah Menengah. Port Dickson, Malaysia Tesis yang dikemukakan kepada Senat Universiti Putra Malaysia.

Mamona-Downs, J., \& Downs, M. (2005). The identity of problem-solving. Journal of Mathematical Behaviour, 24, 385-401. http://dx.doi.org/10.1016/j.jmathb.2005.09.011

Manoy, J. T. (2009) Pemecahan Masalah Matematika oleh Siswa. Prosiding Seminar Nasional Matematika Fakultas MIPA Universitas Negeri Jember.

Mardzellah, M. (2007). Sains Pemikiran dan Etika. Kualalumpur: PTS Professional.

McGregor, D. (2007). Developing Thinking Developing Learning. Poland: Open University Press.

Rahman, S. A., Ghazali, M., \& Ismail, Z. (2003). Integrating Ict In Mathematics Teaching Methods Course: How Has Ict Changed Student Teachers' Perception About Problem Solving. The Mathematics Education into the 21 st Century Project Proceedings of the International Conference The Decidable and the Undecidable in Mathematics Education Brno, Czech Republic, September 2003

Rajagukguk. (2011) Upaya meningkatkan kemampuan pemecahan masalah matematika siswa dengan penerapan teori belajar Bruner pada pokok bahasan trigonometri di kelas X SMA Negeri 1 Kualuh Hulu Aek Kanopan tahun ajaran 2009/2010. Visi, 19(1), 427-442.

Reys, R. E., Lindquist, M. M., Lambdin, D. V., Smith, N. L., \& Suydam, M. N. (2004). Helping Children Learn Mathematics (7th ed.). New York: Wiley.

Schoenfeld, A. H. (1985). Mathematical Problem Solving. New York: Academic Press.

Schoenfeld, A. H. (1992). Learning to think mathematically: Problem solving, metacognition, and sense-making in mathematics. In D. Grouws (Ed.), Handbook for Research on Mathematics Teaching and Learning. New York: MacMillan.

Sukayasa. (2012) Pengembangan Model Pembelajaran Berbasis Fase-Fase Polya untuk Meningkatkan Kompetensi Penalaran Siswa SMP dalam Memecahkan Masalah Matematika Sukayasa. AKSIOMA, Volume 01 Nomor 01 Maret 2012.

Van de Walle, J. (2004). Elementary and middle school mathematics: Teaching developmentally. Boston, MA: Pearson Education.

Wahyudin. (2010). Peranan Problem Solving dalam Matematika. Bandung: FPMIPA UPI.

Yahaya, A., Yahasa, N., \& Zakariyya, Z. (2005). Psikologi Kognitif. Johor Baharu: Penerbit Universiti Teknologi Malaysia.

Yuan, S. (2013). Incorporating Polya's Problem Solving Method in Remedial Math. Journal of Humanistic 
Mathematics, 3(1), 96-107. http://dx.doi.org/10.5642/jhummath.201301.08

\section{Copyrights}

Copyright for this article is retained by the author(s), with first publication rights granted to the journal.

This is an open-access article distributed under the terms and conditions of the Creative Commons Attribution license (http://creativecommons.org/licenses/by/3.0/). 